\title{
MECP2 duplication phenotype in symptomatic females: report of three further cases
}

\author{
Francesca Novara ${ }^{1 *}$, Alessandro Simonati ${ }^{2}$, Federico Sicca ${ }^{3}$, Roberta Battini ${ }^{3}$, Simona Fiori ${ }^{3}$, Annarita Contaldo ${ }^{3}$, \\ Lucia Criscuolo ${ }^{2}$, Orsetta Zuffardi ${ }^{1}$ and Roberto Ciccone $e^{1,4}$
}

\begin{abstract}
Background: Xq28 duplications, including MECP2 (methyl CpG-binding protein 2; OMIM 300005), have been identified in approximately 140 male patients presenting with hypotonia, severe developmental delay/intellectual disability, limited or absent speech and ambulation, and recurrent respiratory infections. Female patients with Xq28 duplication have been rarely reported and are usually asymptomatic. Altogether, only fifteen symptomatic females with Xq28 duplications including MECP2 have been reported so far: six of them had interstitial duplications while the remaining had a duplication due to an unbalanced $X_{\text {; }}$ autosome translocation. Some of these females present with unspecific mild to moderate intellectual disability whereas a more complex phenotype is reported for females with unbalanced $X$;autosome translocations.
\end{abstract}

Findings: Here we report on the clinical features of three other adolescent to adult female patients with Xq28 interstitial duplications of variable size, all including MECP2 gene.

Conclusions: Mild to moderate cognitive impairment together with learning difficulties and speech delay were evident in each of our patients. Moreover, early inadequate behavioral patterns followed by persistent difficulties in the social and communication domains, as well as the occurrence of mild psychiatric disturbances, are common features of these three patients.

Keywords: MECP2, Xq28 duplication, X chromosome inactivation

\section{Background}

Over the last decade, Xq28 duplications including $M E C P 2$ (methyl CpG-binding protein 2; OMIM 300005), have been identified in approximately 140 male patients presenting with hypotonia, severe developmental delay/intellectual disability (DD/ID), limited or absent speech and ambulation, and recurrent respiratory infections [1-25]. Female patients with Xq28 duplication have been rarely reported and are usually asymptomatic. Highly skewed Xchromosome inactivation $(\mathrm{XCI})$ with preferential inactivation of the duplication-bearing $\mathrm{X}$ chromosome has been usually demonstrated in their blood samples [26]. Until recently, fifteen symptomatic females with Xq28 duplications including MECP2 had been reported. Six of them presented with interstitial duplications while in

\footnotetext{
* Correspondence: francesca.novara@unipv.it

'Department of Molecular Medicine, University of Pavia, Pavia, Italy

Full list of author information is available at the end of the article
}

the remaining cases the duplication originated by an $\mathrm{X}$;autosome translocation [3,20,24,25,27-32].

Some of these females present with unspecific mild to moderate intellectual disability whereas a more complex phenotype is reported in subjects with unbalanced $\mathrm{X}$;autosome translocations (Table 1).

Here we report on the clinical features of three other adolescent to adult females patients with Xq28 interstitial duplications of variable size, all including $M E C P 2$ gene, in order to improve the knowledge about phenotype associated with this clinical condition.

\section{Clinical report}

Two out of three patients reported in this paper had a positive family history: intellectual disability (ID) was present in different male relatives of cases 1 and 2. The male twin and the elder brother of case 2 were affected by severe psychomotor delay/intellectual disability and died at 18 months and 23 years of age respectively because of respiratory infections; facial dysmorphisms were 
Table 1 A summary of genetic and clinical features of symptomatic female patients with MECP2 duplication reported so far in literature and including the three cases reported herein (Group A: patients with small interstitial Xq28 duplication, Group B: Xq28 duplication due to X;autosome translocations)

\begin{tabular}{|c|c|c|c|}
\hline & & Group A & Group B \\
\hline Age & & $7-21$ years & 18 months-19 years \\
\hline \multicolumn{4}{|l|}{ Genetic features } \\
\hline Duplicate segment length & & $107.5 \mathrm{~Kb}-700 \mathrm{~Kb}$ & $\begin{array}{l}0.29 \mathrm{~Kb}-16.6 \mathrm{Mb} \text { (for two cases the size is } \\
\text { unknown but cytogenetic visible) }\end{array}$ \\
\hline \multirow[t]{3}{*}{ Inheritance } & de novo & 4 & 8 \\
\hline & Maternal & 5 & 0 \\
\hline & Unknown & 0 & 1 \\
\hline \multirow[t]{3}{*}{$\mathrm{XCl}$} & Random & 6 & 2 \\
\hline & Skewed & 3 & 1 \\
\hline & Unknown & 0 & 6 \\
\hline \multicolumn{4}{|l|}{ Clinical features } \\
\hline Abnormal general conditions & & $5 / 9(55 \%)$ & 9/9 (100\%) \\
\hline Dysmorphic patterns & & $3 / 9(33 \%)$ & $9 / 9(100 \%)$ \\
\hline Delayed motor development & & 4/9 (44\%) & 9/9 (100\%) \\
\hline Abnormal language development & & $6 / 9(67 \%)$ & 9/9 (100\%) \\
\hline Intellectual disability & & $7 / 9(78 \%)$ & $9 / 9(100 \%)$ \\
\hline \multirow[t]{2}{*}{ Mood and behaviour } & Affected & $4 / 9(44 \%)$ & $1 / 9(11 \%)$ \\
\hline & Unknown & $5 / 9(55 \%)$ & $8 / 9(88 \%)$ \\
\hline \multirow[t]{2}{*}{ Social conduct } & Affected & 8/9 (88\%) & 0/9 (0\%) \\
\hline & Unknown & 1/9(11\%) & $9 / 9(100 \%)$ \\
\hline Autistic features & & 4/9 (44\%) & $0 / 9(0 \%)$ \\
\hline Seizures & & 1/8 (13\%) & $3 / 9(33 \%)$ \\
\hline \multirow[t]{2}{*}{ Brain MRI } & Abnormal & 0/9 (0\%) & $3 / 9(33 \%)$ \\
\hline & Unknown & $1 / 9(11 \%)$ & $6 / 9(67 \%)$ \\
\hline
\end{tabular}

Abnormal general conditions: growth retardation, constipation, hypotonia and/or joint laxity.

Dysmorphic pattern: microcephaly, trigonocephaly, facial dysmorphisms, multiple skeletal and/or organs dysmorphisms.

Language development: either delayed or impaired during school-age and adolescence.

Intellectual disability: Group A: either mild or moderate; Group B: severe only.

Brain-MRI: cortical atrophy along with white matter involvement.

present in both. The three pedigrees together with the clinical details for the carriers and patients are reported in Figure 1.

Gestation and delivery were unremarkable in all 3 cases; both pre- and post-natal growth were normal.

Mild signs of early psychomotor retardation and speech delay were recorded in all children by their infancy while feeding and sleep disturbances have been reported since 18 months of age in case 3.

By puberty, mild motor clumsiness was evident in all of them with scarce motor fluidity and mild disturbances of coordination along with hypotonia and joint laxity.

Presently, cognitive functions were affected in all patients. Speech development was markedly delayed in case 1; mild delay was observed in the remaining two. Learning difficulties were present in all. Mild to moderate ID was evident in all patients after intelligence testing administration at different ages (ID was ascertained according to WISC-R scale). In particular case 3 revealed a decline of IQ from borderline at 6 years of age to mild intellectual disability when she was 17 years old. Deficit in adaptive behaviour with early behavioural disturbances were evident in all cases (Table 2). Interestingly, behavioural patterns differed among the patients, both qualitatively and temporally. In case 1 tendency to social withdraw was present in pre-school age lasting until adolescence. Conversely, hyperactivity with attention difficulties were characteristic of cases 2 and 3; some anxiety features get started during adolescence in case 2 , whereas depressive mood along with anxious traits came out at the same age in case 3 . Social conduct 


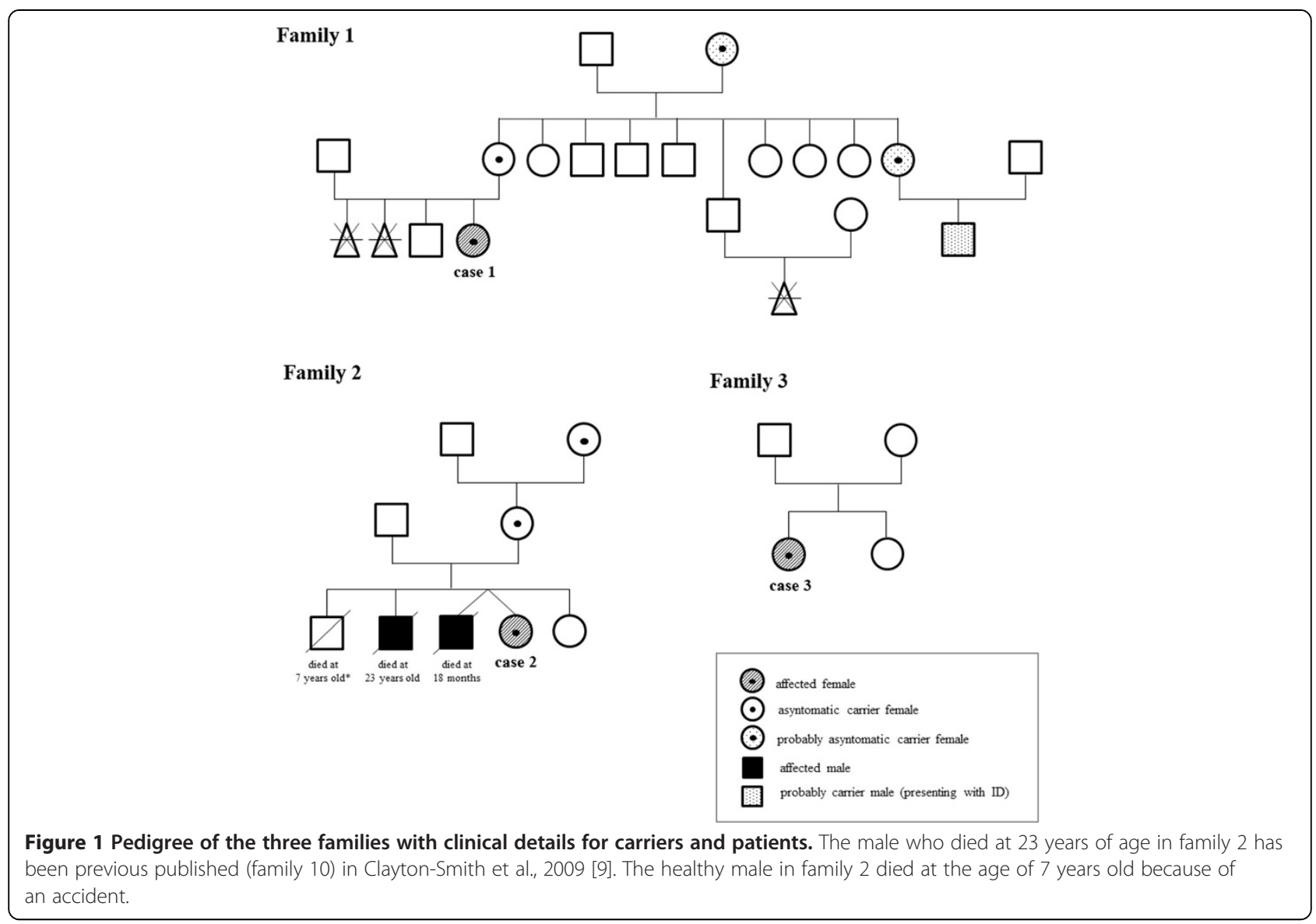

was normal in case 1, it was getting worse over time in case 2 whereas it was always impaired in case 3. None of them showed stereotyped or repetitive behaviours.

Minor facial dysmorphic features were observed only in cases 1 and 2: broad nasal bridge, prognatism, mild ocular hypertelorism (Figure 2).

EEG was normal in case 1, whereas posterior slow waves were recorded in case 3. Head-brain MRI imaging (cases 1 and 3) was normal. EEG and brain MRI were not available in case 2 .

Major clinical findings for all three patients are summarized in Table 2.

Informed consent was obtained for all patients. Parents of cases 1 and 2 gave permission for their photo publication.

\section{Results}

The array-CGH showed a Xq28 duplication in all the three female patients. Case 1: $\operatorname{arr}[$ hg19] Xq28(153,238, 518-153,406,174) $\times 3$ mat, case 2: $\operatorname{arr}[\mathrm{hg} 19] \mathrm{Xq28}(152$, 987,955-153,609,113) $\times 3$ mat and case 3: $\operatorname{arr}[$ hg19] Xq28 (chrX:153,015,806-153,405,806) ×3 dn (probe positions are referred to hg19) (Figure 3).
The duplications presented different sizes: $167 \mathrm{~Kb}, 621$ $\mathrm{Kb}$ and $390 \mathrm{~Kb}$ respectively. In all the cases MECP 2 and IRAK1 were included in the duplication.

$\mathrm{X}$ chromosome inactivation test performed on DNA extracted from blood and saliva showed a random $\mathrm{X}$ inactivation in case 1 and in her mother, who carried the same duplication (case 1: R2/R1 = 3.1 and 2.7 in blood and saliva respectively; mother: $\mathrm{R} 2 / \mathrm{R} 1=2$ and 1.8 in blood and saliva respectively). Case 2 was also tested together with her mother and her maternal grandmother who were both healthy carriers of the Xq28 duplication. The test showed a 100\% skewed inactivation in blood but a random inactivation in DNA extracted from buccal swabs in all of them $(\mathrm{R} 2 / \mathrm{R} 1=0.39, \mathrm{R} 2 / \mathrm{R} 1=0.45, \mathrm{R} 2 / \mathrm{R} 1=$ 0.6 for case 2 , her mother and her grandmother respectively). In case 3 the test showed a skewed X chromosome inactivation both in blood and saliva $(\mathrm{R} 2 / \mathrm{R} 1=14,7$ and 11,7 respectively). In this last case microsatellite analysis demonstrated that the anomaly originated de novo on the paternal X chromosome (data not shown).

\section{Discussion}

MECP2 gene, located on chromosome Xq28, encodes for an essential epigenetic regulator of postnatal brain 
Table 2 Major clinical findings for all three reported patients

\begin{tabular}{ll}
\hline Case $\mathbf{1}$ (14 years) & Case $\mathbf{2}$ (21 years) \\
\hline - two spontaneous abortions & - male twin: facial dysmorphism severe \\
& early delay; death at 18 months of age \\
- one maternal uncle with ID & - one brother: facial dysmorphism severe \\
& developmental delay, seizures, autistic \\
& features, death at 23 years of age
\end{tabular}

Case 3 (19 years)

Physical data

(at birth)

GW

$\mathrm{L}(\mathrm{cm})$

BW $(\mathrm{g})$

$\mathrm{HC}(\mathrm{cm})$

Early development

Walking (months)

Speech onset (years)

Behaviour

School age

Neurological condition

Learning

Intelligence

Communication/social
conduct

Behaviour
40

$49(50 \mathrm{pc})$

2400 (10 pc)

$36(50 \mathrm{pc})$

18

5 (few words) $\rightarrow 12$ (fair)

Difficulty of separation and isolation

Normal

Difficulties

Moderate (IQ 41)

Quiet and withdrawn
Difficulties
39

Not known

3000 (50 pc)

Not known35

13

4

Hyperactivity

Normal

Difficulties

Borderline (IQ NA)

Good

Hyperactivity, attention deficit, impulsiveness
40

$51(50 \mathrm{pc})$

3780 (75 pc)

(50 pc)

15

3

Tantrum

Normal

Difficulties

Borderline (IQ 80 when 6 years)

Difficulties (since 3 years)

Hyperactivity

Adolescence

Neurological condition

Motor coordination

Hypotonia/joint laxity

Intelligence

Communication/social

conduct

Behaviour

Dysmorphic features

Fair

Yes

Scarce (IQ NA)

Difficulties

Quiet and meek

Minor facial dymorphisms (broad nasal bridge, prognatism, mild ocular hypertelorism)

$\begin{array}{ll}\text { Poor } & \text { Fair } \\ \text { Yes } & \text { Yes } \\ \text { Borderline (IQ 84 when15 years) } & \text { Mild (IQ 57 when17 years) } \\ \text { Difficulties } & \text { Difficulties }\end{array}$

Hyperactive, anxious, mood disorder

Minor facial dysmorphisms (broad nasal bridge, prognatism)
Anxious, depressive mood

None

\section{Diagnostics}

\begin{tabular}{|c|c|c|c|}
\hline EEG & Normal & NA & Posterior slow waves \\
\hline MRI & Normal & NA & Normal \\
\hline
\end{tabular}

GW: gestational age; L: length; BW: body weight; HC: head circumference; IQ: intelligence quotient (ascertained according to WISC-R scale); ID: intellectual disability; NA: not ascertained.

development [33]. Loss-of-function MECP2 mutations had been identified as the cause of Rett syndrome, mainly affecting females [34] and initially thought to be lethal in males [22]. Duplications involving MECP2 have been frequently identified in male patients presenting with a different phenotype from that of Rett syndrome and mainly characterized by severe mental retardation, recurrent respiratory infections, epilepsy, cerebellar degenerative change and progressive encephalopathy
[4-6,8,12,14,24]. Whereas the phenotypic effect of MECP2 duplications has already been well documented in males, the clinical implications determined by these rearrangements is still poorly known in females. So far, females with both small intrachromosomal duplications including MECP2 [20,24,29,32] (Figure 3) and large Xq28 duplications resulting from an unbalanced $\mathrm{X}$;autosome translocation have been documented [3,25,27,28,30-32]. In the latter cases (Table 1, group B cases) a more severe 

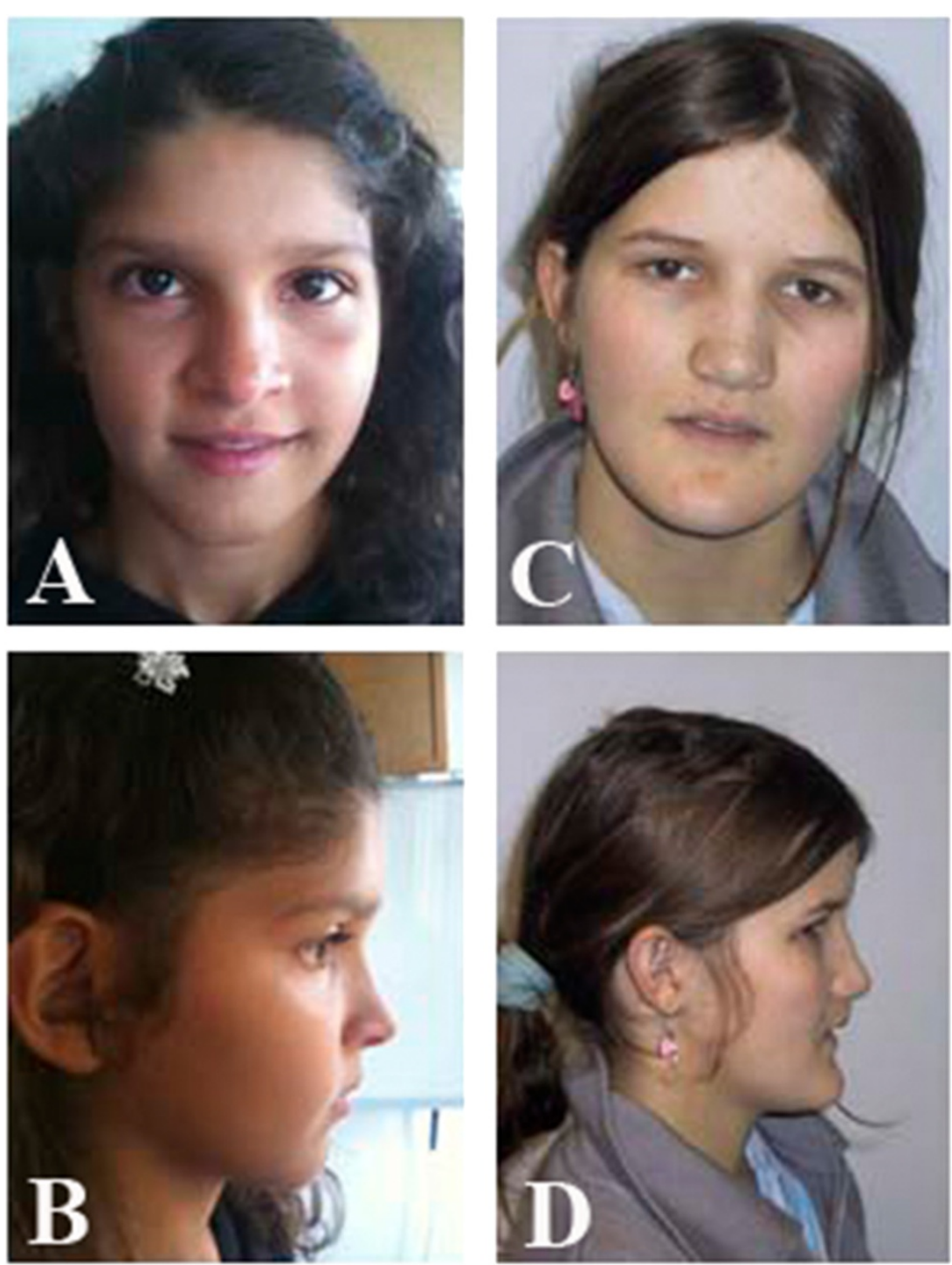

Figure 2 Pictures of case 1 when she was 14-years-old ( $A$ and B) and case 2 at 21 years of age (C and D).

phenotype is present: intellectual disability, abnormal language development and delayed motor development is present in all of them. Moreover epilepsy and abnormal brain MRI are reported in 33\% of X;autosome translocation cases, while autistic features are absent in all of them. This more severe phenotype is likely to be due to the partial monosomy for the portion of the autosome where the Xq was transposed.

Thus, MECP2 is the primary dose-sensitive and critical gene responsible for neurological phenotypes both in males and females. In male mice, the overexpression of Mecp2 causes a progressive neurological disorder, including motor dysfunction, hypoactivity, tremor, ataxia, and premature death; ubiquitous elevated expression also led to lethal heart and skeletal malformations $[35,36]$.
Here we described three further female patients carrying a submicroscopic Xq28 duplication involving MECP2 (Figure 3). Two of them carried a familial Xq28 duplication, but in both cases their mothers did not present any pathological phenotype. Differences in XCI patterns have been hypothesize as responsible for the different phenotypes and outcome in this chromosome imbalance. It is reasonable to assume that the random $\mathrm{XCI}$ is the crucial point leading to the intellectual disability phenotype in symptomatic patients, whereas a highly skewed XCI with a preferential inactivation of the duplicated $\mathrm{X}$ chromosome is a protective factor.

Our experiments to test the $\mathrm{X}$ chromosome inactivation did not reveal any difference between mother and daughter in cases 1 and 2 . Those data did not explain the phenotypic 


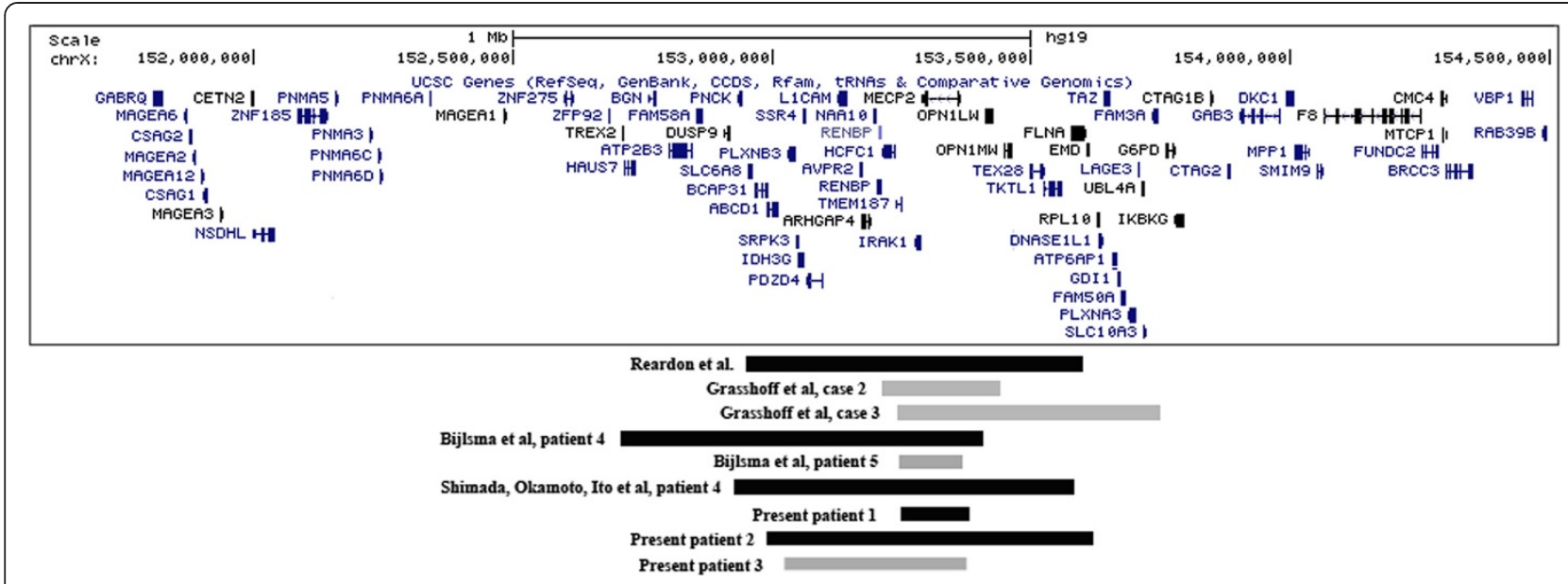

Figure 3 Schematic representation of Xq28 region. All nine female patients with intrachromosomal Xq28 duplication are represented. Familiar cases are in black, while de novo duplications in grey. Gene content of the region is shown from the UCSC Genome Browser version Human February 2009 (hg19).

differences among female carriers of Xq28 duplication both in cases 1 and 2 . However, it is likely that in symptomatic patients the duplicated chromosome $\mathrm{X}$ was preferentially active during the critical stages of embryonic development thus impairing the normal brain development. Moreover, we tested only blood and saliva and we could not determine the $\mathrm{X}$ inactivation status of other tissues.

Despite the different sizes of the identified duplicated regions, IRAK1 was included within each of them. Duplication of this gene has been hypothesized to be responsible for the severe and recurrent respiratory infections in duplicated males [13]. This feature, that is the main cause of death in males, has been rarely reported in female patients [ 24 patient $1,28,29$ patient 1,32 patients $1,2,3$ and 5 ] and was absent in all the three cases reported herein.

Mild to moderate cognitive impairment together with learning difficulties and speech delay were evident in each of our patients. It is noteworthy that the patient 3, with de novo microduplication, presented with an apparent disease progression, as shown by the mildly declined score of her cognitive abilities (see Table 2). Similarly MECP2 mutations in Rett syndrome females lead to a gradual loss of acquired skills around the first year of age [37], associated with postnatal microcephaly, a feature not present in $M E C P 2$ duplicated females.

In the only patient (case 3 ) with de novo Xq28 microduplication, the anomaly originated on the paternal $\mathrm{X}$ chromosome. Similarly, a paternal origin was demonstrated in other two females with de novo Xq28 interstitial duplications [32] in agreement with the $\mathrm{X}$ chromosome vulnerability at male meiosis [38].

Early inadequate behavioral patterns followed by persistent difficulties in the social and communication domains, as well as the occurrence of mild psychiatric disturbances are common features of these three patients. Hyperactivity with attention deficit was reported in 2 out of three patients during school age, whereas symptoms such as anxiety, or a depressive mood developed during the adolescence. The occurrence of behavioural changes, as well as the onset of psychiatric disturbances during the adolescence, is a common event in children affected by mild difficulties (such as our three cases) and it can be related to their social difficulties. None of them developed autistic features as described in other female patients affected by a similar condition [29, 32 case 4$]$.

\section{Conclusion}

In conclusion we could not highlight the reason for differences in the phenotypes of $M E C P 2$ duplicated females: neither the size of the duplication nor the X-inactivation pattern as assessed in blood or other easy available tissues, may predict the outcome of these subjects. This highly variable clinical presentation makes genetic counseling difficult in terms of prognosis, especially in prenatal cases.

\section{Methods}

Written informed consent was obtained from the parents of the patients for publication of this manuscript and any accompanying images.

\section{Molecular karyotyping}

Molecular karyotyping was performed by using the Agilent array $180 \mathrm{~K}$ (Human Genome CGH Microarray, Agilent Technologies, Santa Clara, CA, USA) for all patients according to the manufacturer's protocol. Data analysis was performed using Agilent Genomic Workbench Standard Edition 6.5.0.58.

Probe positions are referred to hg19. 


\section{X-inactivation test}

The X-chromosome inactivation (XCI) patterns were analyzed for all patients by genotyping the CAG repeats in the androgen receptor gene. $1 \mu \mathrm{g}$ of DNA (extracted from blood or saliva) was digested at $37^{\circ} \mathrm{C}$ overnight with HpaII restriction enzyme (New England Biolabs, Beverly, MA, USA) in a total volume of $50 \mu$ l containing $5 \mu \mathrm{l}$ buffer $10 \times$ and $2 \mu \mathrm{l}$ of enzyme $(5 \mathrm{U} / \mu \mathrm{l})$. After digestion the enzyme was inactivated at $65^{\circ} \mathrm{C}$, and PCR was performed on $200 \mathrm{ng}$ digested/undigested DNAs with specific primers for HUMARA locus. One of the primer set was labeled with the fluorescent dye (FAM). The PCR mixture contained $10 \times$ Taq reaction buffer $(200$ $\mathrm{mM}$ Tris pH 8.4, $500 \mathrm{mM} \mathrm{KCl}), 50 \mathrm{mM} \mathrm{MgCl} 2$, dNTPs $(2 \mathrm{mM})$, primers $(20 \mu \mathrm{M}), 2.5$ units of Taq polymerase (Invitrogen, Carlsbad, CA, USA) for a final volume of $50 \mu \mathrm{l}$. Amplification was carried out in a temperature cycler with the following PCR cycling profile: preheating at $95^{\circ} \mathrm{C}$ for $5 \mathrm{~min}$, followed by $95^{\circ} \mathrm{C}$ for $45 \mathrm{sec}, 60^{\circ} \mathrm{C}$ for $30 \mathrm{sec}, 72^{\circ} \mathrm{C}$ for $30 \mathrm{sec}$ for 28 cycles, and a final extension at $72^{\circ} \mathrm{C}$ for $7 \mathrm{~min}$. The PCR samples were loaded onto a $2 \%$ agarose gel, stained with ethidium bromide, and directly visualized under ultraviolet (UV) illumination. Analysis of fluorescent samples was performed using ABI 3100 Genetic Analyzer (Applied Biosystems).

Because CAG repeats site and the methylation sites of the androgen receptor gene were included in the PCR fragments, PCR products could only be obtained from the undigested DNA derived from the inactive X-chromosome. Analysis of PCR amplicons was performed using ABI 3100 Genetic Analyzer (Applied Biosystems) to determine the PCR product size and obtain peak areas. Finally, the XCI patterns were classified as random (a ratio higher than 20:80 and lower than 80:20) or skewed (higher than 80:20 or lower than 20:80) according to Allen et al., 1992 [39].

\section{Microsatellite analysis}

Genotyping of polymorphic loci in the patients with de novo Xq28 duplications and in her parents was performed by amplification with primers labeled with fluorescent probes (ABI 6-Fam and 8-Hex), followed by analysis on ABI 3100 Genetic Analyzer (Applied Biosystems, Foster City, CA). Primers were designed using the database tool Tandem Repeats Finder (http://tandem.bu.edu/trf/ trf.intermediate.submit.html).

\section{Abbreviations}

MECP2: Methyl CpG-binding protein 2; ID: Intellectual disability; EEG: Electroencephalogram; MRI: Magnetic resonance imaging; PCR: Polymerase chain reaction; array-CGH: Array comparative genomic hybridization; XCl: X-Chromosome inactivation.

\section{Competing interests}

The authors declare that they have no competing interests.

\section{Authors' contributions}

FN carried out all the molecular cytogenetic analysis and drafted the manuscript. AS, FS, RB, SF, AC and LS collected all clinical data, conceived the work, and participated in its design, drafted and revised the manuscript. OZ and RC conceived the work, and participated in its design, drafted and revised the manuscript. All authors analyzed all results and read and approved the final manuscript.

\section{Acknowledgements}

This work was supported by Telethon 2010 (GGP10121) and PRIN 2010-2011 (20108WT59Y_003) to Dr. Zuffardi.

\section{Author details}

${ }^{1}$ Department of Molecular Medicine, University of Pavia, Pavia, Italy. ${ }^{2}$ Medical School Department of Neurological and Movement Sciences-Neurology (Child Neurology and Psychiatry), University of Verona, Verona, Italy. ${ }^{3}$ Department of Developmental Neuroscience, IRCCS Stella Maris, Calambrone, Pisa, Italy. ${ }^{4}$ National Neurological Institute C. Mondino, Pavia, Italy.

Received: 10 October 2013 Accepted: 17 December 2013

Published: 28 January 2014

\section{References}

1. Clayton-Smith J, Watson P, Ramsden S, Black GC: Somatic mutation in MECP2 as a non-fatal neurodevelopmental disorder in males. Lancet 2000, 356:830-832.

2. Meins M, Lehmann J, Gerresheim F, Herchenbach J, Hagedorn M, Hameister K, Epplen JT: Submicroscopic duplication in Xq28 causes increased expression of the MECP2 gene in a boy with severe mental retardation and features of Rett syndrome. J Med Genet 2005, 42:12

3. Sanlaville D, Prieur M, de Blois MC, Genevieve D, Lapierre JM, Ozilou C, Picq M, Gosset P, Morichon-Delvallez N, Munnich A, Cormier-Daire V, Baujat G, Romana S, Vekemans M, Turleau C: Functional disomy of the Xq28 chromosome region. Eur J Hum Genet 2005, 13:579-585.

4. Van Esch H, Bauters M, Ignatius J, Jansen M, Raynaud M, Hollanders K, Lugtenberg D, Bienvenu T, Jensen LR, Gecz J, Moraine C, Marynen P, Fryns $J P$, Froyen G: Duplication of the MECP2 region is a frequent cause of severe mental retardation and progressive neurological symptoms in males. Am J Hum Genet 2005, 77:442-453.

5. Friez MJ, Jones JR, Clarkson K, Lubs H, Abuelo D, Bier JA, Pai S, Simensen R, Williams C, Giampietro PF, Schwartz CE, Stevenson RE: Recurrent infections, hypotonia, and mental retardation caused by duplication of MECP2 and adjacent region in Xq28. Pediatrics 2006, 118:1687-1695.

6. del Gaudio D, Fang P, Scaglia F, Ward PA, Craigen WJ, Glaze DG, Neul JL, Patel A, Lee JA, Irons M, Berry SA, Pursley AA, Grebe TA, Freedenberg D, Martin RA, Hsich GE, Khera JR, Friedman NR, Zoghbi HY, Eng CM, Lupski JR, Beaudet AL, Cheung SW, Roa BB: Increased MECP2 gene copy number as the result of genomic duplication in neurodevelopmentally delayed males. Genet Med 2006, 8:784-792.

7. Lugtenberg D, de Brouwer AP, Kleefstra T, Oudakker AR, Frints SG, Schrander-Stumpel CT, Fryns JP, Jensen LR, Chelly J, Moraine C, Turner G, Veltman JA, Hamel BC, de Vries BB, van Bokhoven H, Yntema HG: Chromosomal copy number changes in patients with non-syndromic $\mathrm{X}$ linked mental retardation detected by array CGH. J Med Genet 2006, 2006(43):362-370.

8. Smyk M, Obersztyn E, Nowakowska B, Nawara M, Cheung SW, Mazurczak T, Stankiewicz P, Bocian E: Different-sized duplications of Xq28, including $M E C P 2$, in three males with mental retardation, absent or delayed speech, and recurrent infections. Am J Med Genet B Neuropsychiatr Genet 2008, 147B:799-806

9. Clayton-Smith J, Walters S, Hobson E, Burkitt-Wright E, Smith R, Toutain A, Amiel J, Lyonnet S, Mansour S, Fitzpatrick D, Ciccone R, Ricca I, Zuffardi O, Donnai D: Xq28 duplication presenting with intestinal and bladder dysfunction and a distinctive facial appearance. Eur J Hum Genet 2009, 17:434-443

10. Echenne B, Roubertie A, Lugtenberg D, Kleefstra T, Hamel BC, Van Bokhoven $H_{\text {, }}$ Lacombe D, Philippe C, Jonveaux P, de Brouwer AP: Neurologic aspects of MECP2 gene duplication in male patients. Pediatr Neurol 2009, 41:187-191.

11. Kirk EP, Malaty-Brevaud V, Martini N, Lacoste C, Levy N, Maclean K, Davies L, Philip N, Badens C: The clinical variability of the MECP2 duplication 
syndrome: description of two families with duplications excluding L1CAM and FLNA. Clin Genet 2008, 75:301-303.

12. Lugtenberg D, Kleefstra T, Oudakker AR, Nillesen WM, Yntema HG, Tzschach A, Raynaud M, Rating D, Journel H, Chelly J, Goizet C, Lacombe D, Pedespan $J M$, Echenne B, Tariverdian G, O'Rourke D, King MD, Green A, van Kogelenberg M, Van Esch H, Gecz J, Hamel BC, van Bokhoven H, de Brouwer AP: Structural variation in Xq28: MECP2 duplications in 1\% of patients with unexplained XLMR and in $2 \%$ of male patients with severe encephalopathy. Eur J Hum Genet 2009, 17:444-453.

13. Prescott TE, Rodningen OK, Bjornstad A, Stray-Pedersen A: Two brothers with a microduplication including the MECP2 gene: rapid head growth in infancy and resolution of susceptibility to infection. Clin Dysmorphol 2009, 18:78-82.

14. Ramocki MB, Peters SU, Tavyev YJ, Zhang F, Carvalho CM, Schaaf CP, Richman R, Fang P, Glaze DG, Lupski JR, Zoghbi HY: Autism and other neuropsychiatric symptoms are prevalent in individuals with MeCP2 duplication syndrome. Ann Neurol 2009, 66:771-782.

15. Velinov M, Novelli A, Gu H, Fenko M, Dolzhanskaya N, Bernardini L, Capalbo A, Dallapiccola B, Jenkins EC, Brown WT: De-novo 2.15 Mb terminal Xq duplication involving MECP2 but not L1CAM gene in a male patient with mental retardation. Clin Dysmorphol 2009, 18:9-12

16. Bartsch O, Gebauer K, Lechno S, van Esch H, Froyen G, Bonin M, Seidel J, Thamm-Mücke B, Horn D, Klopocki E, Hertzberg C, Zechner U, Haaf T: Four unrelated patients with Lubs $X$-linked mental retardation syndrome and mental retardation syndrome and different Xq28 duplications. Am J Med Genet A 2010, 152A:305-312.

17. Belligni EF, Palmer RW, Hennekam RC: MECP2 duplication in a patient with congenital central hypoventilation. Am J Med Genet A 2010, 152A:1591-1593.

18. Campos M Jr, Churchman SM, Santos-Rebouças CB, Ponchel F, Pimentel MM: High frequency of nonrecurrent MECP2 duplications among Brazilian males with mental retardation. J Mol Neurosci 2010, 41:105-109.

19. Fernández RM, Núñez-Torres R, González-Meneses A, Antiñolo G, Borrego S: Novel association of severe neonatal encephalopathy and Hirschsprung disease in a male with a duplication at the Xq28 region. BMC Med Genet 2010, 11:137.

20. Reardon W, Donoghue V, Murphy AM, King MD, Mayne PD, Horn N, Birk ML: Progressive cerebellar degenerative changes in the severe mental retardation syndrome caused by duplication of MECP2 and adjacent loci on Xq28. Eur J Pediatr 2010, 169:941-949.

21. Breman AM, Ramocki MB, Kang SH, Williams M, Freedenberg D, Patel A, Bader PI, Cheung SW: MECP2 duplications in six patients with complex sex chromosome rearrangements. Eur J Hum Genet 2011, 19:409-415.

22. Budisteanu M, Papuc SM, Tutulan-Cunita A, Budisteanu B, Arghir A: Novel clinical finding in MECP2 duplication syndrome. Eur Child Adolesc Psychiatry 2011, 20:373-375.

23. Honda S, Satomura S, Hayashi S, Imoto I, Nakagawa E, Goto Y, Inazawa J, Japanese Mental Retardation Consortium: Concomitant microduplications of MECP2 and ATRX in male patients with severe mental retardation. $J$ Hum Genet 2012, 57:73-77.

24. Shimada S, Okamoto N, Hirasawa K, Yoshii K, Tani Y, Sugawara M, Shimojima K, Osawa M, Yamamoto T: Clinical manifestations of Xq28 functional disomy involving MECP2 in one female and two male patients. Am J Med Genet A 2013, 161A:1779-1785.

25. Shimada S, Okamoto N, Ito M, Arai Y, Momosaki K, Togawa M, Maegaki Y, Sugawara M, Shimojima K, Osawa M, Yamamoto T: MECP2 duplication syndrome in both genders. Brain Dev 2013, 35:411-419.

26. Ramocki MB, Tavyev YJ, Peters SU: The MECP2 duplication syndrome. Am J Med Genet A 2010, 152A:1079-1088

27. Makrythanasis P, Moix I, Gimelli S, Fluss J, Aliferis K, Antonarakis SE, Morris MA, Béna F, Bottani A: De novo duplication of MECP2 in a girl with mental retardation and no obvious dysmorphic features. Clin Genet 2010, 78:175-180.

28. Auber B, Burfeind P, Thiels C, Alsat EA, Shoukier M, Liehr T, Nelle H, Bartels I, Salinas-Riester G, Laccone F: An unbalanced translocation resulting in a duplication of Xq28 causes a Rett syndrome-like phenotype in a female patient. Clin Genet 2010, 77:593-597.

29. Grasshoff U, Bonin M, Goehring I, Ekici A, Dufke A, Cremer K, Wagner N, Rossier E, Jauch A, Walter M, Bauer C, Bauer P, Horber K, Beck-Woedl S, Wieczorek D: De novo MECP2 duplication in two females with random X-inactivation and moderate mental retardation. Eur J Hum Genet 2011, 19:507-512.
30. Bialer MG, Taff I, Shanmugham A, Lagrave D, White BJ: De novo trisomy Xq28-qter detected by subtelomeric FISH screening. Am J Hum Genet 2003, 73:30

31. Lachlan KL, Collinson MN, Sandford RO, van Zyl B, Jacobs PA, Thomas NS: Functional disomy resulting from duplications of distal $\mathrm{Xq}$ in four unrelated patients. Hum Genet 2004, 115:399-408.

32. Bijlsma EK, Collins A, Papa FT, Tejada MI, Wheeler P, Peeters EA, Gijsbers AC, van de Kamp JM, Kriek M, Losekoot M, Broekma AJ, Crolla JA, Pollazzon M, Mucciolo M, Katzaki E, Disciglio V, Ferreri MI, Marozza A, Mencarelli MA, Castagnini C, Dosa L, Ariani F, Mari F, Canitano R, Hayek G, Botella MP, Gener B, Mínguez M, Renieri A, Ruivenkamp CA: Xq28 duplications including MECP2 in five females: expanding the phenotype to severe mental retardation. Eur J Med Genet 2012, 55:404-413.

33. Gonzales ML, LaSalle JM: The role of MeCP2 in brain development and neurodevelopmental disorders. Curr Psychiatry Rep 2010, 12:127-134.

34. Amir RE, Van den Veyver IB, Wan M, Tran CQ, Francke U, Zoghbi HY: Rett syndrome is caused by mutations in X-linked MECP2, encoding methyl-CpG-binding protein 2. Nat Genet 1999, 23:185-188.

35. Collins AL, Levenson JM, Vilaythong AP, Richman R, Armstrong DL, Noebels JL, David Sweatt J, Zoghbi HY: Mild overexpression of MeCP2 causes a progressive neurological disorder in mice. Hum Mol Genet 2005, 13:2679-2689.

36. Alvarez-Saavedra M, Carrasco L, Sura-Trueba S, Demarchi Aiello V, Walz K, Neto JX, Young Jl: Elevated expression of MeCP2 in cardiac and skeletal tissues is detrimental for normal development. Hum Mol Genet 2010, $19: 2177-2190$

37. Kim HJ, Kim SH, Kim HD, Lee JS, Lee YM, Koo KY, Lee JS, Kang HC: Genetic and epileptic features in Rett syndrome. Yonsei Med J 2012, 53:495-500.

38. Giglio S, Pirola B, Arrigo G, Dagrada P, Bardoni B, Bernardi F, Russo G, Argentiero L, Forabosco A, Carrozzo R, Zuffardi O: Opposite deletions/ duplications of the $\mathrm{X}$ chromosome: two novel reciprocal rearrangements. Eur J Hum Genet 2000, 8:63-70

39. Allen RC, Zoghbi HY, Moseley AB, Rosenblatt HM, Belmont JW: Methylation of Hpall and Hhal sites near the polymorphic CAG repeat in the human androgen-receptor gene correlates with $\mathrm{X}$ chromosome inactivation. Am J Hum Genet 1992, 51:1229-1239.

doi:10.1186/1755-8166-7-10

Cite this article as: Novara et al:: $M E C P 2$ duplication phenotype in symptomatic females: report of three further cases. Molecular Cytogenetics 2014 7:10

\section{Submit your next manuscript to BioMed Central and take full advantage of:}

- Convenient online submission

- Thorough peer review

- No space constraints or color figure charges

- Immediate publication on acceptance

- Inclusion in PubMed, CAS, Scopus and Google Scholar

- Research which is freely available for redistribution 